\title{
A REVIEW OF MAIN SUSTAINABILITY CHALLENGES IN ALUMINIUM DIE CASTING INDUSTRY
}

\author{
UDC 502.131.1:621.74:669.71
}

\section{Emilija Kozhovska}

LTH Castings, Ohrid, Macedonia

\begin{abstract}
Aluminium die casted parts are in demand by many industries, and their relatively low costs, lightweight, as well as accurate dimensions and shapes give reason to predict that aluminium will be dominant metal in industry for years to come. Aluminium die casting process includes a variety of materials and energy resources. Die casting process uses significant quantities of energy, as well as auxiliary materials like oil-based lubricants and cooling water. This article presents an outline of the environmental, social, and economic sustainability issues related to aluminium die casting process.
\end{abstract}

Key words: Sustainability, aluminium, die casting, environment

\section{INTRODUCTION}

The most important challenge during 21 st century is how to develop and maintain sustainable societies - to enable future generations to build upon the advancements of those who have come before. Thus in 1987 the Brundtland Commission report sustainable development is defined as "development that meets the needs of the present without compromising the ability of future generations to meet their own needs."

The 2005 United Nations World Summit [1] further posited that three interdependent and mutually reinforcing pillars exist to support sustainable development: economic development, social development, and environmental protection. These three interdependent pillars have been referred to as the triple bottom line (i.e., people, profit, and planet) and other related terms that evoke a holistic world view [2].

Pressure die casting process today has become integral to manufacturing industry and can be used to create complex geometric parts with relative ease, irrespective of the size of part. Aluminium is a lightweight material exhibiting good dimensional stability, mechanical properties, machinability, and thermal and electrical conductivity.

Received February 23, 2017 / Accepted June 1, 2017

Corresponding author: Emilija Kozhovska

LTH Castings, 15-ti Korpus 89, 6000 Ohrid, Macedonia

E-mail: emilija_kozovska@yahoo.com 
Sustainability-related impacts result from operations and activities that aluminium pressure die casting process use to convert input materials and energy sources into marketable products. Material (aluminium) and energy are necessary inputs of die casting process; wastes and emissions, which are generally classified as outputs, are, in turn, inputs to other industrial and natural systems, where their impact is felt socially, environmentally, and economically.

Following the taken perspective on energy, resource and material intensities and on the hierarchically organized aluminium die casting value chain, its sustainability relevance is reviewed below in the paper.

\section{Alumunium Die CASTing PROCess}

Basically, high pressure aluminium die casting is a manufacturing process in which molten metal (aluminium) is injected with a die casting machine using considerable pressure into a steel mold or die to form products. This process requires relatively complex machinery. During the industrial process the aluminium alloy is molten, shaped on die casting molds and put forward to different types of sub - processes in order to fulfill the client's requirements.

The aluminium pressure die casting is a widely used manufacturing process that produces two-thirds of the aluminium castings used in the automotive industry [3].In order to meet the challenges of competition, the industry is continuously seeking to improve its overall performance. While costs, delivery time and quality have been traditionally in the focus of producers, growing concerns about environmental burdens (energy consumption, air emissions and waste generation) created by manufacturing has forced the industry to seek adequate solutions. Notably, pressure die casting processes can be energy and water intensive with high percentage of losses of high cost aluminium as trim wastes [4].

The process chain inside a foundry can be described as a set of activities or interlinked sub processes [5], shown in figure 1. Every die casting foundry runs the following value adding activities, which are mandatory to produce die casted parts with a defined set of characteristics and functionalities [5]:

- melting (of an aluminium alloy)

- casting (shaping the alloy into a semi-product)

- finishing (several operating processes for surface finishing and product cleaning)

Within the system boundaries a number of processes are considered. These include processes that are contributing to pollution or waste streams. 


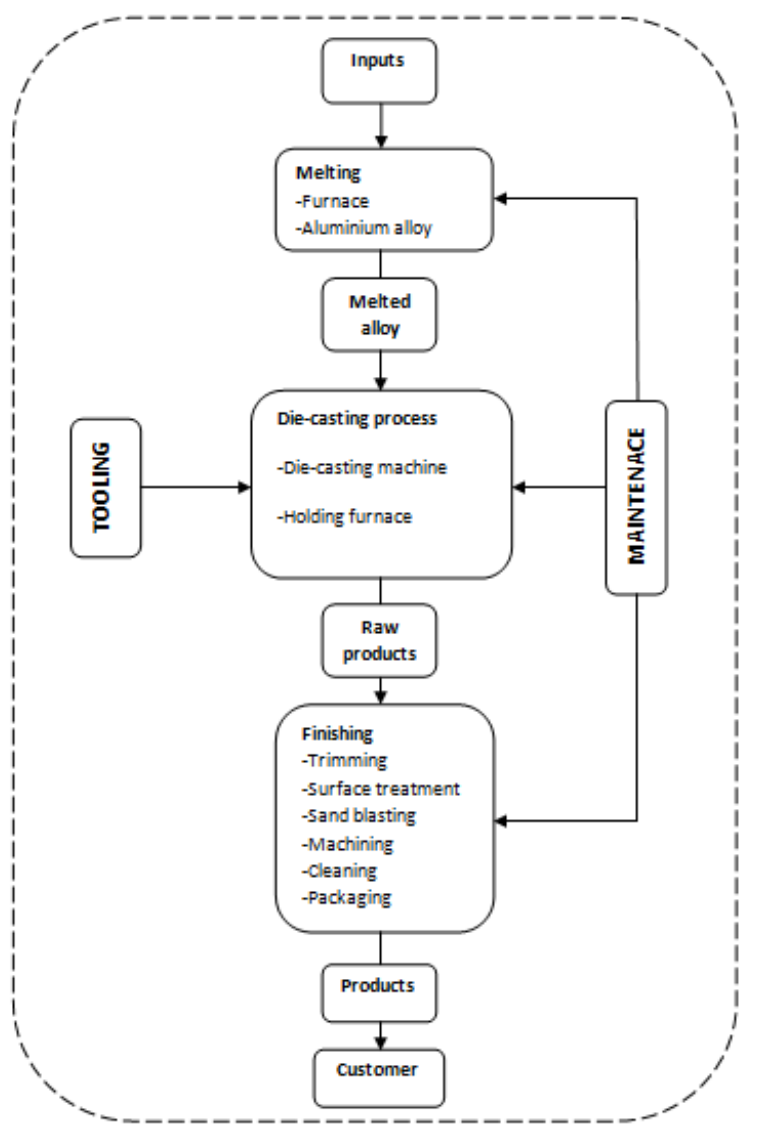

Fig. 1 Scheme of die casting process and sub processes

\section{EnVIRonmental Aspects of Aluminium Die CAsting Process}

Over the past few decades, environmental issues have received more attention, and a variety of environmental measures have been set forth, in order to quantify the ecological footprint. The environmental problems caused by the aluminium pressure die casting industry are various and are related to emissions released to air, soil and water.

The in- and out-flows of aluminium and investigated operating inputs, shown in Fig. 2 can be complex. In particular, a number of waste streams of aluminium and operating inputs occur right throughout the process.

Air pollution is caused by emissions of metals from aluminium alloy, compounds released during fuel combustion, hydrogen fluoride (HF) emissions from the use of fluxing agents to remove impurities from molten alloy, and volatile organic compounds (VOCs) from the use of lubricants [6].

Solid waste includes aluminium dross and ceramic lining from furnaces. Other types of solid waste are ceramic abrasives and steel shot from operations taking place during the metals surface finishing [6]. 
Liquid effluents are a mixture of water, oils and detergents from pressure die casting and sub processes. These effluents in most cases are treated in the plant's wastewater treatment sites. In addition, wastewater treatment plants discharge sludge, oils and grease. Water pollution is caused by losses of emulsion used to lubricate the die casting moulds. These emissions, wastes and effluents cause toxicity problems for people, local community as well as terrestrial and aquatic ecosystems.

Figure 2 illustrates the industrial practice of the aluminium die casting process and presents the different sub processes involving the material and energy flow as well as the pollutants and wastes released.

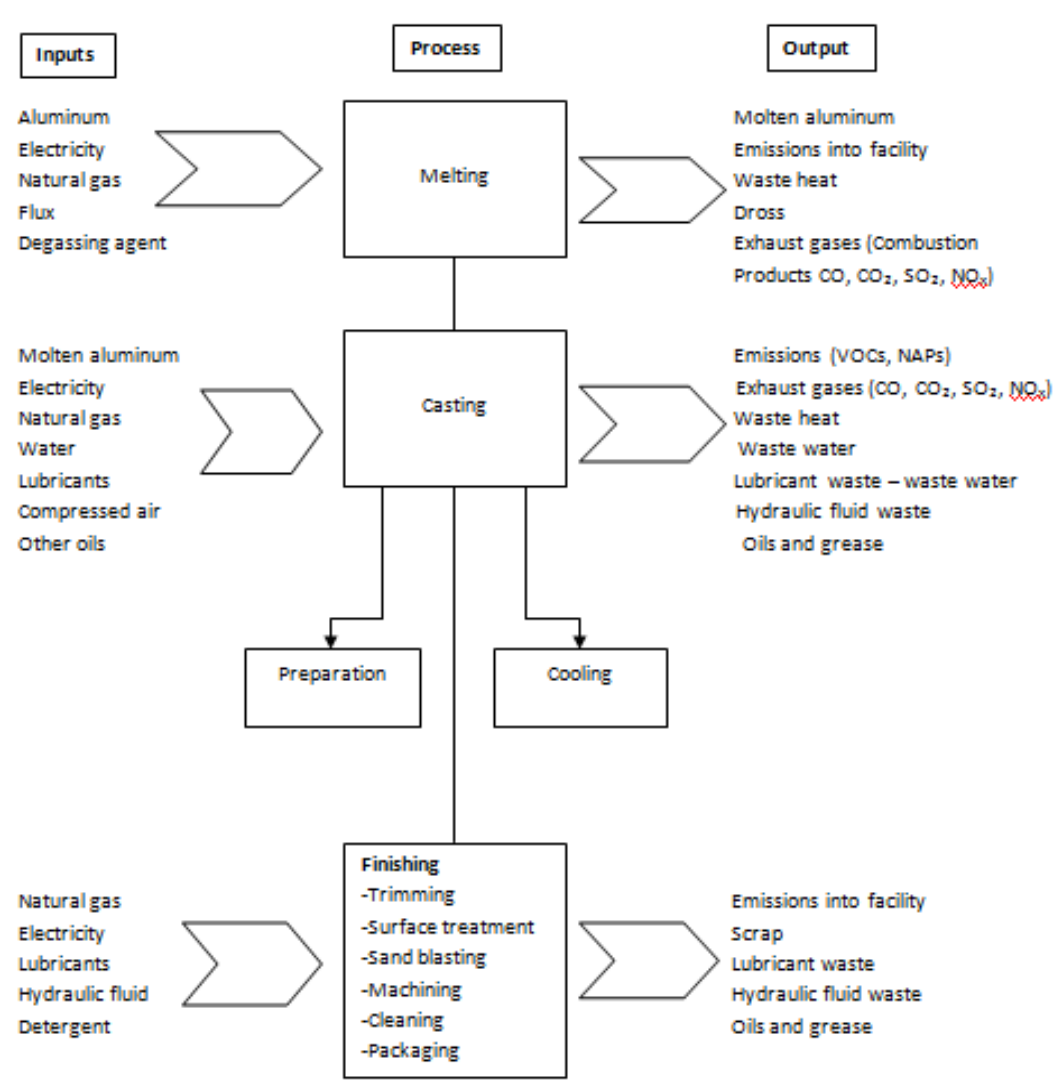

Fig. 2 Inputs and outputs in die casting process and sub processes

\section{- Melting}

The melting process consists of heating of the aluminium to the required temperature $\left(680-700^{\circ} \mathrm{C}\right)$ in a furnace. According to the literature, the most furnaces use gas (TNG, $\mathrm{CNG}$ ) rather than electricity, since gas furnaces are still more prevalent in die casting foundries [7]. Consequently, using a gas furnace, results in release of a portion of combustion products inside the facility: 
- Gases from fuel combustion: (CO, CO2, SO2, NOx, etc.)

The melting process includes the addition of "degassing" agents, which are used for removing magnesium and gas from certain metal alloys and flux which in often used to remove oxides in the molten metal during the process. Although flux is used, some dross (solid impurities on the surface of the metal due to oxidation) still forms and must be removed from the melt [8].As a result of melting process oxides and ashes are generated, containing molten metal components (metal oxides, flux components, etc.). Dross and slag have high metal content, but their composition varies according to the melting conditions. The sludge contains mainly metal oxides which are accumulated at the bottom of a melting furnace.

\section{- Die Preparation}

The die preparation operation consists of the cooling and lubrication of the die at the beginning of each cycle [8]. Die casting lubricants are used to facilitate the removal of the product from mold. Die lubricantsare active in a particular temperature range; therefore, cooling water is sprayed for cooling the surface of the mold. The use of lubricants has various environmental impacts. Approximately $30 \%$ of the die lubricant used makes it onto the die surface, while the rest goes to waste [9].Since a mold lubricant is sprayed on a surface of die, a part of it is released to air in form of volatile organic compounds (VOCs) and hazardous air pollutants (HAPs), and an excess amount of lubricant is removed in wastewater.

\section{- Cooling}

The cooling operation involves the solidification of the molten aluminium within the die, through the circulation of cooling water [8].Cooling water is continuously pumped around the foundry in a closed cycle. Polluted cooling water is released in wastewater.

\section{- Trimming}

During the cooling period, the metal material in the channel solidifies and adheres to the casting. Using a manual process (sawing or cutting) or a trimming press, the excess materials must be trimmed from the casting. The trim press is hydraulically controlled, and a lubricant is applied to the press prior to the trimming. Therefore, trimming operation results with release of hydraulic fluid and lubricant waste which are removed through wastewater system.

\section{- Shot blasting}

Abrasive finishing (shot blasting) is a process in which metal balls are blasted onto the casting product surface. The application of this process depends on the type of casting products. Shot blasting releases metal dust that consists of the particles of the casting product and abrasive material. Metal dust coming out from the process is handed over to the waste disposal and a portion of metal dust is emitted to the air.

\section{- Machining}

Machining operation involves mechanicaltreatmentof casted parts in order to meet customer requirements.An output from machining process is mixture of chips or cutting scrap, and oil and emulsion also come out of the process. The oil used in the machining process is generally reused, but some of it becomes waste and is disposed of together with waste metal (aluminium chips). Moreover, the water-soluble cutting agent is treated by wastewater treatment system and released to water bodies [10]. 


\section{- Cleaning}

Cleaning process involves removal of adhered metal chips or oil from the products after machining. As inputs in cleaning process, organic solvents and water are used. Therefore, cleaning operation results in release of wastewater and/or waste organic solvent containing metal chips. A portion of volatile organic solvents are used, and are released to the air.

\section{Social AsPects of Aluminium Die - CASTING PROCEss}

The social dimension of sustainability comprises several aspects, including physiological and psychological effects on employees, public perception, community engagement, and customer loyalty.

Measuring the social performance from engineering point of view is a greater challenge than environmental performance measurement, and social metric development is in the very early stages [11].

However, social aspects arerelated to awareness of the responsibility towards employees, business partners and the local environment in which manufacturing plants operate.

Several social aspects related to die casting are briefly reviewed in a table below.

Table 1 Social aspects due to aluminium die casting process

\section{Social aspects related to aluminium die casting process}

\section{Occupational health and safety}

- Workers are exposed to heat, noise, dust, chemicals, gases and pollutants, which requires implementation of good engineering practices in the field of safe and healthy working environment

- Operation of heavy machinery requires specialized training and monitoring

- Handling of hazardous and/or hot materials requires specialized training and monitoring [12]

- Development of skills of employees requires their lifetime knowledge development (internal and external trainings)

\section{Local community impacts}

- Creating jobs, reducing unemployment in the community

- Heat and noise from die casting process may have impact and generate complaints from locals despite meeting environmental regulations [12]

- Vehicles entering and leaving the plant disturb locals (e.g. noise, pollution and hazards)

- Local habitats may be particularly vulnerable to the materials, substances and processes used (e.g. drawing water from limited local supply, and impact of metal dust or heat on flora and fauna).

- Supply chain activities may impact land and water, affect air quality, and disrupt communities and local flora and fauna

- Continuously planning processes would lead to better use of raw materials, energy and natural resources and would promote healthy life styles

Product responsibility

- Manufacturers should implement the latest technology trends

- They should follow technology trends, continuously putting innovations into practice

- They should be oriented to customers in order to improve product quality 


\section{ECONOMIC Aspects of Aluminium Die CASTING PROCESS}

The economic dimension of sustainability incorporates economic growth considerations into environmental protection and social progress. The economic dimension of sustainability refers to the company's impacts on the economic systems at local, national, and global levels. This consist of aspects associated with economic conditions of a company's stakeholders, direct economic value generated and distributed, including revenues, operating costs, employee compensation, financial assistance received from the government, development of infrastructure and also indirect economic impacts. In the table below, economic advantages and disadvantages due to aluminium pressure die casting process are shown.

Table 2 Economic aspects of aluminium die casting process

\begin{tabular}{lll}
\hline \multicolumn{2}{c}{ Economic aspects of aluminium die casting process } \\
\hline Advantages & Disadvantages \\
\hline $\begin{array}{l}\text { High degree of automation, downstream } \\
\text { connectivity of particular processes and } \\
\text { therefore high productive capacity }\end{array}$ & $\begin{array}{l}\text { Die casting process is generally not } \\
\text { profitable for small lot sizes of pieces }\end{array}$ \\
- $\begin{array}{l}\text { Good applicability of aluminium casted } \\
\text { parts, because of their lightweight } \\
\text { properties and applicability (mainly in }\end{array}$ & $\begin{array}{l}\text { Hie casting machines [13] } \\
\text { die costing molds and }\end{array}$ \\
$\begin{array}{l}\text { automotive industry) } \\
\text { High degree of economical profitability } \\
\text { as a result of high level of automation } \\
\text { and productivity }\end{array}$ & $\begin{array}{l}\text { Labour intensive industry - exposure to } \\
\text { highour costs and risk of industrial }\end{array}$ \\
\hline
\end{tabular}

\section{CONCLUSION}

The paper describes the sustainability issues of aluminium die casting industry. The issues considered include environmental, economic and social implications of aluminium die casting process activities.

Primary, inputs and outputs of die casting process and related sub processes were considered from environmental point of view. Aluminium pressure die casting is water and energy intensive process and uses variety of chemicals, mainly oil based lubricants, which contributes to a number of environmental problems, emissions in air, water and soil which makes considerable footprint of environment.

Socially die casting foundries should continuously work on raising the awareness of the responsibility toward employees, business partners and community, which means promoting health and safety practices and providing safe working environment.

Given the rising demand for die casted parts, die casting industries should strive to integrate industrial, societal, and natural processes and systems to create a holistic, closed-loop network that produces and manages materials, products, and services in a sustainable manner. The theoretical review of environmental, social and economic issues compiled in this study provide a baseline for creating an information model for a sustainable die casting manufacturing process. Future work should include a case study in order to quantify the environmental impacts, and further demonstrate sustainability assessment in this field of industrial production. 


\section{REFERENCES}

1. UNEP, 2005 "World Summit Outcome Document," United Nations General Assembly, Document A/2060/L. 1, September 15, http://www.unep.org/greenroom/ documents/outcome.pdf, Accessed February 27, 2011.

2. Haapala, Karl R., Fu Zhao, Jaime Camelio et al. Review of Engineering Research in Sustainable Manufacturing, July 2013 published in Journal of Manufacturing Science and Engineering

3. A. Brown, J.R., 1999, Foseco Non-Ferrous Foundryman's Handbook. In: Brown, J.R., (Eds.), Butterworth-Heinemann, Oxford.

4. A. Tharumarajah, Benchmarking aluminium die casting operations, Resources, Conservation and Recycling, June 2008

5. Neto B, Kroeze C, Hordijk L, Costa C (2009a) Inventory of pollution reduction options for an aluminum pressure die casting plant. Resour Conserv Recycl 53:309-320

6. Belmira Neto, MIKADOa Decision Support Tool for Pollution Reduction in Aluminium Pressure Die Casting, April 2007

7. Dalquist, S., Gutowski T., "Life Cycle Analysis of Conventional Manufacturing Techniques: Die Casting", December 2004, LMP Working Paper LMP-MIT-TGG-03, 19/12/2004

8. Megan F. Watkins, Kevin W. Lyons, Mahesh Mani, S.K. Gupta, SUSTAINABILITY CHARACTERIZATION FOR DIE CASTING PROCESS, Proceedings of the ASME 2013 International Design Engineering Technical Conferences and Computers and Information in Engineering Conference IDETC/CIE 2013, August, 2013, Portland, Oregon, USA

9. Roberts, M. J., 2003, "A Modified Life Cycle Inventory of Aluminum Die Casting," Rep. Geelong: Deakin University

10. Japan Die casting association, Die - casting industry, March 2002

11. Jørgensen, A., Bocq, A., Nazarkina, L., and Hauschild, M., 2007, "Methodologies for Social Life Cycle Assessment,” Int. J. Life Cycle Assess., 13(2), pp. 96-103.

12. Manufacturing Skills Australia, Sustainability issues in metal casting \& forging, http://www.sustainabilityskills.net.au/wp-content/uploads/2012/07/Sustainability-issues-in-metal-castingand-forging_June12.pdf

13. T. Heinemann, Energy and Resource Efficiency in Aluminium Die Casting, Springer International Publishing Switzerland 2016

\section{PREGLED GLAVNIH IZAZOVA ODRŽIVOSTI U INDUSTRIJI LIVENJA ALUMINIJUMA}

Izliveni aluminijumski delovi se zahtevaju u mnogim industrijama, a njihovi relativno niski troškovi izrade, lake težine, kao i tačne dimenzije i oblici, su razlog predvidjanja da će aluminijum $u$ narednim godinama biti dominantan metal $u$ industriji. Proces livenja aluminijuma obuhvata različite materijale $i$ energetske resurse. Proces livenja koristi značajne količine energije, kao $i$ pomoćne materijale kao što su maziva na bazi ulja i vodu za hlađenje. U ovom radu prikazan je pregled pitanja životne sredine, socijalne $i$ ekonomske održivosti vezanih za proces livenja aluminijuma.

Ključne reči: Održivost, aluminijum, livenje, životna sredina 